\title{
A MEDEA CALLED WALLY \\ RACE, MADNESS AND FASHION IN PAUL HEYSE'S NOVELLA MEDEA
}

Heike Bartel

ABSTRACT

In the extensive tradition of adaptations of the Medea myth in German-speaking literature Paul Heyse's novella Medea (1898) has been often overlooked. However, the fact that it is the first text to introduce the tragic heroine from classical mythology as 'black' gives it particular relevance. This contribution provides an analysis of the text with emphasis on Heyse's portrayal of the Medea/Wally character at the interface of late nineteenth-century discourses about race, colonial politics, female sexuality and social class.

Die deutschsprachige Literatur weist eine lange Tradition von Adaptionen des Medea-Mythos auf, in der Paul Heyses Novelle Medea (1898) jedoch häufig übersehen wird. Die Tatsache, dass dieser Text der erste ist, in dem die tragische Heldin der griechischen Mythologie als 'Schwarze' dargestellt wird, verleiht ihm jedoch eine besondere Bedeutung. Der folgende Beitrag liefert eine Analyse des Textes mit Schwerpunkt auf Heyses Darstellung von Medea/Wally im Schnittpunkt der Diskurse um Kolonialpolitik, Rasse, weibliche Sexualität und soziale Klasse am Ende des 19. Jahrhunderts.

Paul Heyse (b. 1830 in Berlin, d. 1914 in Munich) might not be the first writer who springs to mind in connection with the unruly, revolutionary and provocative Medea, the infamous infanticidal mother of classical mythology. He was a court poet appointed by the Bavarian king Maximilian II, a 'Dichterfürst' mainly catering for the taste of his nineteenth-century bourgeois readership and devoted to classical ideals of beauty in the footsteps of Goethe and Schiller. He was widely read and extensively published during his lifetime and produced around 180 novellas. However, to a contemporary reader now he seems to be too settled and tame to take on this 'dynamite material' that is Medea. Perhaps as a consequence, his novella Medea written in 1898 has made hardly any impact amongst the adaptations of the classical myth in German-speaking literature that include provocative and innovative dramas.

Heyse's work in general has not succeeded in continuing to generate interest. This lack of reception after his death, despite his being awarded the Nobel Prize for literature in 1910, might stem from extensive criticism by the Naturalists who regarded his work as outdated. Damning criticism came in particular from the Naturalists' leading publication, Die Gesellschaft. Its publisher 
Michael Georg Conrad saw Heyse only as relevant 'in einem bestimmten Münchener Milieu von engbeschränktem Schönheitsempfinden und duseliger Behäbigkeit’.

Heyse's Medea participates in a long tradition of reception of the Medea myth by writers and artists throughout the centuries. Prominent examples after Heyse include Hans Henny Jahnn, Marie Luise Kaschnitz, Anna Seghers, Heiner Müller and Christa Wolf, to name but a few. ${ }^{2}$ All these versions to some extent refer back to Euripides' 431 B.C. tragedy Medea and engage in one way or another with the infamous Colchian wife of the Greek hero Jason. Although it is disputed whether it was Euripides' innovation to have Medea commit the murder of the two sons she has with Jason in order to hurt her estranged husband (in older versions they are murdered by the Corinthians or suffer an accidental death) it is particularly Euripides' portrayal of this infanticidal Medea that has survived, repulsed, fascinated and inspired throughout the centuries. It can be said that Euripides' tragedy has become so canonical because he portrays her as a highly complex character. His Medea is a vulnerable female from a foreign land but she also talks and behaves in a way that is usually attributed to male characters, she is victim but also aggressor, desirable woman and undesirable witch. She is human and eventually superhuman, escaping without being punished for her crimes in a dragon-drawn chariot, and, importantly, she is the mother who kills her own children. It is this complexity that led Bernard Knox to formulate his provocative statement regarding Euripides: '[T]he field is wide open for every man to make his own Euripides $-[\ldots]$ the political dramatist $[\ldots]$ the feminist, the radical, the reactionary, or the mere bungler' ${ }^{3}$ The complexity in Medea's character that embraces a simultaneity of contrasting elements and her ability to challenge and threaten an existing status quo can be seen as two key elements that have not only been taken up in Medea adaptations throughout the centuries but also seem to be guarantors for her longevity. In the following analysis of Heyse's novella Medea we will examine how this writer at the turn of nineteenth century transfers the unruly classical heroine into the bourgeois context of Munich society and Medea becomes Wally.

From a genre aspect alone Heyse's Medea stands out against the mighty Medea dramas of 
the German-speaking adaptations before him which overshadow this short text. In addition to Heyse's changes of key aspects of the myth, to which we will turn below, it is also this change of genre from drama to prose that affects his reception of the myth and results in a Medea adaptation that can be seen as considerably less dramatic and more 'domesticated' than its predecessors. With regard to its form, Heyse's Medea does not strive in any way to build a link to Euripides or, in fact, to any other dramatic version. It stays within the framework of the genre of the novella which saw its high point in German literature during the nineteenth century and had at the time in Heyse an important representative.

One factor that certainly influenced Heyse's choice of the Medea myth for his novella was his admiration for Grillparzer. In 1855, 43 years before his Medea, the 25-year-old Heyse already showed his engagement with the Austrian dramatist in writing to his parents: 'Ich lese so allerlei [...]. Neulich wieder zwei Grillparzer'sche Tragödien, Medea und des Meeres und der Liebe Wellen. Eine Schande, daß er im besten Zuge ist, vergessen zu werden. ${ }^{4}$ It is this very Medea tragedy, a trilogy first performed in 1821, to which Heyse makes particular reference in his 1898 novella of the same title. ${ }^{5}$ His aim to revive his admired Grillparzer and bring him (again) to public notice may have been as much the reason for his choice as the human tragedy embedded in the classical material and the possibility of linking the topic to contemporary racial discourse.

Heyse's text starts where a performance of Grillparzer's Medea ends. He introduces a group of theatre-goers who have just seen the drama on stage. Heyse embeds his Medea story into a framing narrative where time and place do not have any symbolic function but historic, literary, cultural and even linguistic references are made to a particular German context. The conversation of this mixed group is dominated by the horror of infanticide introduced in the play, and the oldest of the ladies tells a 'true' story that involves a young male relative of hers and a woman called Wally who is the Medea character in the novella. However, there is no indication that the character is based on a real case or, in fact, that Heyse ever encountered a 'Wally character'.

In contrast to the immediacy of Grillparzer's (and other) Medea dramas, Heyse's novella 
introduces several shifts of perspective. The reader does not experience the direct speech of Medea on stage but learns through the voice of a narrator about the effect the performance of Grillparzer's adaptation has on a group of theatregoers. Out of several responses in this group, one is explored further and leads to a second, female narrator. The myth is viewed through several lenses, with each one distancing the reader further from a 'mythic space' and 'zooming in' on a particular situation 'in unserem lieben München’ ${ }^{6}$ at the turn of the nineteenth century. To enhance this effect Heyse drops contemporary hints throughout the novella that create a particular framework for the story, e.g. by naming the leading actress in Grillparzer's play, Fanny Janauschek, a well-known actress at the time and famous for her international success as Medea. In addition, there are references to local dialect and contemporary fashion as well as historical figures.

The myth is not treated as offering a model for all human behaviour and thinking. On the contrary, Heyse establishes a socio-culturally and psychologically very detailed and hence very particular setting for his Medea that does not draw the reader into the complex relationship of identification followed by horror but keeps the boundaries very clear from the beginning. Wally is introduced as a seamstress who has a child out of wedlock and is, importantly, a 'Mulattin' and thus economically, morally and racially positioned at the margins of the bourgeois Munich society in which the novella is set. Heyse portrays her as clearly outside the established order unlike Euripides' Medea who is of royal descent, married to Jason and initially accepted into Greek society by the chorus despite being a foreigner. Sarah Iles Johnston stresses that it is her access to the 'self' that makes the Medea of antiquity (and her sisters in spirit) so threatening, revolutionary and disturbing:

Not only does her checkered career allow authors and artists to explore the opposing concepts of self and other, as she veers between desirable and undesirable behavior, between Greek and foreigner; it also allows them to raise the disturbing possibility of otherness lurking within self - the possibility that the 'normal' carry within themselves the potential for abnormal behavior, that the boundaries expected to keep our world safe are not 
impermeable. ${ }^{7}$ [emphasis: in original]

To Wally this access to the 'self' is clearly denied throughout the novella. In fact, one main aim of Heyse's text can be seen as not to question - like Euripides - but to cement concepts that clearly keep 'self' and 'other' apart. Wally's 'abnormal' behaviour - she breaks down mentally and ends up killing her child - confirms her extreme otherness. Although her infanticide is condemned as horrific, it is introduced more as a psychological insight into an extreme and alien condition humaine that is not applicable to 'normal' society. Wally's radical deed is thus explained and defused and she herself kept at arms' length from the 'self' of 'normal' society. As a result, Heyse's protagonist does not get underneath the skin of her readership like the Medea from 431 B.C. but is literally put away at the end. Sectioned and confined in a strait-jacket, she does not ride her 'dragon into the future' like her classical ancestor. ${ }^{8}$ Heyse leaves the readers not in an apocalyptic tableau of destruction (Jahnn) or a severely questioned world order (Grillparzer) but with their world and its boundaries intact. According to Urzula Bonter such final reassurance is typical for Heyse's novellas, always ending in a way which 'versöhnt [...] das bürgerliche Publikum mit der vorausgegangenen Grenzüberschreitung' ${ }^{9}$

Supporting the thesis of a 'safe and sectioned' Medea is the fact that Heyse's main protagonist does not carry the name of her wild and threatening sister but a typical southern German name that sounds even more 'homely' in its abbreviated form: Wally. ${ }^{10}$ Between the names Medea and Wally lies a clear contrast that juxtaposes images of Bavaria with the foreign and barbarian shores of Colchis and sets off Euripides' tragedy against examples of 'Heimatliteratur' with titles like Geierwally, the 1873 novel by Wilhelmine von Hillern. The immense disparity in style from the high drama of Grillparzer and Euripides to Heyse's 'moralisierender und betulicher Novelle'11 that is literally a piece of dinner conversation further contributes to this contrast. In his renaming of Medea we can see Heyse's aim to move away from the openness of the classical myth and towards the particular case that is at the centre of the novella and embedded in the socio-cultural and racial discourse of the time. 
'Die Vorstellung war zu Ende' (319) is the start of Heyse's Medea. 'Die Vorstellung' is a performance of Grillparzer's adaptation of the classical myth. Apart from the nod to Grillparzer, this opening includes another intertextual reference as it evokes the first sentence of Goethe's Wilhelm Meisters Lehrjahre: 'Das Schauspiel dauerte sehr lange.' Here, Goethe, who was much admired by Heyse, famously signals the interweaving of theatre and 'real' life in his 'Bildungsroman' and theatre novel. In Goethe's text the 'Vorstellung' does, in fact, continue for several chapters and the theatrical world with its costumes, role reversals and historic and literary references infiltrates the world of the novel. In Heyse's Medea we have a similar situation. Medea's infanticide keeps haunting the theatregoers. After the final curtain falls, play and 'real life' are linked in the heated debate about 'Abgründe gibt es im Gemüte / Die tiefer als die Hölle sind' (321) and infanticidal mothers that leads to the story of Wally. Like Goethe's novel where the dressingup, cross-dressing and undressing of the protagonists does not stop when the curtain falls, Heyse's novella and his 'real-life' Medea prominently feature clothes which play an important role in constructing the character and marking the interface of race, body, female sexuality and class.

Wally is a seamstress and clothes are an essential part of her professional and private life. Her very first introduction four pages into the novella makes this clear:

[...] ein seltsames Gesicht von einer sehr fremdartigen Häßlichkeit. Ein [...] Frauenzimmer in einem Anzuge, den man heutzutage - das Wort war damals noch nicht erfunden durchaus schick nennen würde, mit einem eleganten schwarzen Samthütchen, von dem drei rote Federn über die kurze Stirn hereinnickten. (322) [emphasis: in original] Rather than being portrayed in a dress that clearly marks the otherness that usually characterises the Medea figure, Heyse's Wally is dressed in the latest fashion. However, her clothes highlight rather than disguise her otherness. Her attire, although not foreign in itself, is almost too elegant and 'schick' and emphasises that she is different rather than helping her to fit in. It gives the reader a strong indication of her ultimate fate: an attempt to fit into society that is from the beginning destined to fail. We can find racial stereotypes and reactionary bourgeois thinking deeply ingrained 
in the attitude of the woman who acts as a narrator. The fact that her dislike of Wally does not prelude her from feeling empathy with her shows the complex grammar of racist attitude. In a telling phrase that intrinsically links foreignness and ugliness, Wally's 'fremdartige Häßlichkeit' is the first thing the narrator notices about her, and Wally's 'seltsames Gesicht' is framed and highlighted rather than disguised. At the core of this reaction lies Wally's ethnicity which her 'schwarze[s] Samthütchen' gives away before the narrator even gets to the colour of her skin: Wally is a 'Mulattin'. ${ }^{12}$ The reader's gaze is guided along Wally's clothing and the red feathers on her black velvet hat point to her key feature and main characteristic: 'ein breites, stumpfnasiges Mulattengesicht' (322). This introduction of a 'mixed race' Medea marks the most striking innovation in Heyse's short text. Heyse's protagonist with the homely German name Wally has a 'black' African grandfather, and the contrast of black and gold, darkness and light distances her even further from the classical Medea whose grandfather is Helios, the sun god. Wally is the second generation offspring of a marriage between a 'white' German woman, 'Madame Wally', who worked successfully first in Munich and then in Paris in the fashion industry, and a 'black' Frenchman, ‘dem Kammermohren eines der Söhne Lois Phillips’ (323). The hardworking German and the 'Sohn der Wildnis' (323), who turns out to be a lazy drunk and wife-beater, have a 'hellbraunes Töchterchen' (324), Wally's mother. After the death of her father, caused by too much absinth and 'faule[m] Leben' (324) this 'light-brown' offspring marries a similarly no-good Frenchman, Wally's father, who is, however, 'white'. After the death of Wally's grandmother, mother and daughter leave France to go back to Germany where Wally's mother runs a 'Putzwarengeschäft' in Lower Franconia. She is hardworking, careful with money and her business is a success which is attributed by the female narrator to the fact that '[da]s deutsche Blut scheint stärker in ihr gewesen zu sein, als das mohrische' (325). Wally inherits her mother's business and moves to Munich to work as a seamstress who visits her customers at home, 'oder, wie man hier sagt, "auf Stöhren [...] gehen"” (325). The regional expression indicates that Wally, despite her background, starts out as accepted by the ladies of Munich's bourgeois society and 'erfreute sich 
trotz ihrer Häßlichkeit allgemeiner Beliebtheit' (323). However, the narrator drops hints throughout indicating that this integration is only superficial and will not last. In particular, her comment that Wally attends church regularly, 'doch glaube ich nicht, daß sie [...] jemals [im Gebetbuch] las' (327) hints at the fact that Wally will never be a fully accepted part of society.

The female narrator is also one of Wally's customers and at her house the seamstress meets and falls desperately in love with the narrator's dashing young male relative with failing ambitions to be an artist. The exotic otherness and particularly the figure of this 'kleine [...] Vogelscheuche' (323) spurs him on to make a conquest of her. He seduces and then abandons her. Wally has a son out of wedlock who is the image of his handsome artist-father and doted on by his mother. She is desperately hurt when a couple of years later during an accidental meeting the 'liederliche Strick' of a father (349) shuns her and their son. When he ends up marrying another woman, a 'schlanke weiße Gestalt' (349), Wally, unlike the classical Medea, is not able to go through with attacking the bride with poison. Although she has an opened bottle of vitriol in her pocket, Wally cannot bring herself to carry out the acid attack on the bride's face. From here Wally grows more and more deranged and turns to hating her son because '[d]ie Kröte ist der ganze Vater' (352). After a failed attempt to kill herself and her son with poisonous gas from the kitchen oven Wally strangles the child. The function and motivation for Wally's infanticide is very different from that of the classical Medea. Crucially, the father is not interested in his son and does not even acknowledge his fatherhood. For the classical infanticide, however, the motivation is to hurt and destroy the unfaithful husband who is bound by (marriage-)oath to Medea by eradicating his lineage. Heyse puts the focus to a greater extent on Wally thus shifting Euripides' concentration on the relationship between Jason and Medea solely to this 'mulatto' Medea in Munich and her position in or rather on the verge of society. The end of Heyse's novella does not see a triumphant Medea escape. Instead, Wally goes completely insane and is admitted to a mental asylum until her death. Sectioned, her 'verdunkelte[s] Gehirn' (355) seems finally to match her 'black' outer appearance.

Whilst most Medea adaptations from Euripides to Grillparzer clearly indicate Medea's dark 
and threatening yet also alluring otherness through elements that can be cunningly disguised, particularly her magic powers, Heyse's is the first Medea in the German literary tradition who is explicitly racially marked through her skin colour and 'Mulattenphysiognomie' (327). In turn, her behaviour, despite her ultimate infanticide, is rather tame for a Medea character, especially as Wally does not show any supernatural powers. From the start Heyse links her otherness to external features that signal Wally's ethnicity, and he contributes with his reading of the classical myth to the contemporary racial discourse.

The introduction of skin colour as an external signal for otherness in Heyse's novella signals a turning point in the long tradition of Medea figures and marks a new and extensive 'Entwicklungsreihe, in der die “dunklen Seiten” Medeas zum äußeren Erscheinungsmerkmal stilisiert werden und die "Barbarin" als "Negerin" markiert wird., ${ }^{13}$ Jahnn's drama Medea (1926) where she is introduced as 'Negerin' is often mentioned in this context while Heyse's text is lesser known. Between Grillparzer's 'white-skinned' Medea (1822) whose black veil and Dark Arts indicate her dark side and Jahnn's African Medea with her ‘black' skin, Heyse's 'mulatto' Medea/Wally is an important step indicating the future characterisation and description of Medea and, importantly, the integration of a racial discourse into the adaptation of the classical material. Whilst Jahnn's black Medea has been extensively researched with regard to the question of race, there has been very little research on Heyse's Medea; in recent studies only Inge Stephan mentions Heyse's novella. $^{14}$

Heyse is far removed from what Christoph Steskal calls Jahnn's 'kombinierte Rassismusund Zivilisationskritik' and 'tabuverletzende Provokation'. ${ }^{15}$ The 'black' skin and African background of Jahnn's Medea are valued as positive by him and seen as signs of a more natural, fulfilled and intact culture. However, Marianna Thalden comments perceptively that 'Jahnn's black Medea is much less an individual human being than an embodiment of uncomplicated female sexuality' and a 'caricature of black womanhood that created a sensation on the expressionist stage during the 1920 's'. ${ }^{16}$ 
Heyse's Wally is described as 'ein wunderliches Geschöpf' (326) who from the start subtly irritates the reader by indicating that something is not quite balanced about her: 'Sie war $[\ldots]$ aus scheinbar widersprechenden Elementen zusammengesetzt.' (326) Heyse repeatedly uses terms that indicate contrast and disarray to describe her character, and her ultimate mental collapse can be viewed as the unfortunate yet inevitable climax of a long-established inner conflict. Contradictory elements also characterise Wally's external appearance. Her 'Mulattenphysiognomie' (327) is starkly contrasted in its 'Häßlichkeit' to her 'reizende, üppige Gestalt' (326) which stands out almost provocatively and is sexually alluring underneath her buttoned-up clothing. The contrast between her 'Mulattengesicht' and her body is further highlighted by the fact that men only show interest in her when she appears masked at 'Fasching' as a faceless female body, and her artistseducer insists on keeping the light off when he lures her into his studio, 'um auch an [ihr] eine Eroberung zu machen' (330). Wally has accepted this mark of 'ugliness' and deems herself not worthy to find a proper husband, yet she shows great adoration for beautiful people, especially her seducer, 'der schönste Mensch, der ihr je vorgekommen' (332). Most telling, though, is the narrator's comment on Wally's 'geschmackvolle' and simple clothing which is contrasted to her 'unbezwingliche[m] Hang zu Goldschmuck und blitzenden Steinen, wie man sie bei Völkern auf einer niederen Kulturstufe findet' (326). This contrast clearly discloses an anthropological approach that contributes to the racial discourse of Heyse's time. Links between 'black' Africans and animals, monkeys in particular, indicate the next 'steps' down on this 'cultural ladder': Wally's mother in her childhood is likened to an 'Äffchen, das es im Grunde war, immer aufs Lächerlichste herausgeputzt' (324), and Wally's ultimate madness is described as 'tierisches Brüten’ (355).

Wally's tragic fate is never to fit in fully and always to give away the otherness that lurks 'unbezwinglich' within herself. However, unlike the situation at the start of Euripides' Medea, Heyse's narrator is able to 'read' Wally's underlying otherness, from the beginning clearly positioning her outside the established order and thus considerably reducing the threat that she may pose to it. Here, clothing and accessories play an important role as cultural indicators for ethnic 
otherness: Wally's magpie-like fascination with precious stones that links her to a 'niedere Kulturstufe'; the almost over-fashionable clothing for herself and her son that echoes the ridiculous outfits of pet monkeys or the liveried 'Kammermohr'; the sexual symbolism of her black velvet hat with the 'nodding' red feather; her profession as a seamstress that links her to her mother and the 'exotischen Laden' (324) of her grandmother in Paris; and the fact that her unruly curly hair always escapes from underneath any (German) headgear. In addition, we can detect the first signs of Wally's mental disarray as the eventual culmination of her otherness and 'inner darkness' when she starts neglecting her outer appearance, and going out without a hat signals that she starts losing her head, 'den die krausen Haare wirr umgaben' (347); her last 'dress' is consequently the strait-jacket in the mental asylum.

Wally's inner split and contrasting appearance echoes Herbert Uerlings' comments on 'mulattoes' in the colonial discourse to which we will turn later: 'Im kolonialen Diskurs is nie ganz klar, wo die Mulatten stehen: Sind sie “dankbare Kinder und loyale Bürger” oder trojanische Pferde, potentielle Verräter [...]? Sind sie weiß oder schwarz? Gehören sie zur Welt der Väter oder der Mütter? ${ }^{, 17}$ At the core of the juxtaposition within Wally that brings the 'widersprechenden Elemente' within herself to collision point lies her mixed race: 'Von mütterlicher Seite ein starker Sinn für Ordnung, Ehrbarkeit und Solidität bis zum Pedantischen. Daneben rührte sich in ihrem Blut zuzeiten [...] eine kindische Phantasterei, das Erbteil des afrikanischen Großpapas' (326). The fact that she is a 'mulatto' of the second generation is of vital importance for Heyse's myth adaptation. Wally is literally torn inside, despite her best efforts she can never harmonise the heritage from her negatively connoted grandfather's (and father's) side and her German 'Mutterwitz' (327). Heyse explains her unfortunate fate as predetermined by her 'Blut' descent. Unlike Euripides' Medea whose outsider status derives from her foreignness, Heyse's Wally is the product, the text implies the victim, of a mixed marriage. In Heyse's construction she is born with inherent contradictions that will ultimately lead to her mental breakdown and infanticide. With its repeated references to 'Blut' and the emphasis on the incompatibility of 'deutsche[m] Blut' and 
'mohrische[m]' (325) this 1898 text participates in what Anette Dietrich identifies as a

'Biologisierung des Rassenbegriffs mit den aufkommenden Bevölkerungswissenschaften und den Diskursen um [...] "Rassenhygiene" und Sozialdarwinismus'. ${ }^{18}$ Heyse's repeated emphasis on Wally's pale 'Mulattengesicht', particularly her 'Mulattennase und la bouche énorme' (328), and the comments on the Grillparzer actress Fanny Janauscheck '[die] ja den Stempel der böhmischen Rasse deutlich ausgeprägt in ihren unregelmäßigen Zügen trägt [...] neben der zahmen Nase und den sanften Wangen der [...] Königstochter' (329), can be linked to the upcoming pseudo-sciences of physiognomy and phrenology that impute an ultimately racist connection between facial features and character or claim that personality traits can be derived from the shape of the skull. ${ }^{19}$ In addition, Kai Stalmann points out the link between the constructed concepts of both 'blacks' and 'Jews' in the racial discourse of the early twentieth century: 'Im Kontext des rassen- und gesellschaftsbiologischen Begriffs der "Entartung” galten Juden und Neger gleichermaßen als Gefahren. Juden zählten innerhalb der Antithese des "hellen Schönen” und des "häßlichen Schwarzen" zu den letzteren. ${ }^{20}$ However, this text from 1898 also has to be viewed within the context of colonial politics with Africa at the centre of interest of Heyse's contemporaries. The anthropologist and feminist historian Ann Laura Stoler stresses that in nineteenth-century Europe race had become 'the organizing grammar of an imperial order in which modernity, the civilizing mission and "the measure of man" were framed". ${ }^{21}$ And with respect to Germany Fatima El-Tayeb and Anette Dietrich, among others, stress the importance of German colonies for the development of a racial world order with particular emphasis on gender and sexuality. ${ }^{22}$ On a cultural level, especially in the arts, there was an increased fascination with African subjects, presented as highly 'sanitised', unrealistic or caricatured. Heyse's text itself speaks for this, and it is no coincidence that Wally's seducer is a painter who shows a mixture of sexual and 'artistic' interest in her 'Augen wie schwarze Diamanten [...], und Ihre Figur -- ' (336). It is noteworthy that the first publication of Heyse's Medea (by Carl Krabbe in Stuttgart) was extensively illustrated by the artist René Reinicke whose images add a different level to the discussion of racist sexualisation of 'black bodies', e.g. 
Wally is given a very dark skin tone, and there is a strong emphasis on her body, be it whilst lying on a bed with half-exposed breasts or nursing her baby. ${ }^{23}$

However, Heyse's text also offers concrete colonial links with its references to France where Wally's grandmother met her grandfather. The former 'Kammermohr' (323), a luxurious and fancily-dressed exotic status symbol of the French and later German court, particularly evokes colonial culture and politics. ${ }^{24}$ Here, Heyse makes references to the French colonial discourse where 'mulattoes' played a significant role. Uerlings outlines this role with particular reference to Haiti and Kleist's novella Die Verlobung in St. Domingo (1811) which we can assume was known to the well-read Heyse. With reference to the colonial politics of the eighteenth and nineteenth century Uerlings links the loss of control during the Haitian Revolution, which lies at the centre of Kleist's texts, with the rise of a 'mulatto' population. 'Es waren nicht die Schwarzen, sondern die Mulatten, deren Anspruch auf politische Emanzipation erst den Konvent 1791/92 in Bewegung brachte und damit - aus der Sicht der Revolutionsgegner - die Kolonie in den Ruin trieb. ${ }^{25}$ This perceived problem lies literally at the conception of the threat to the established racial, cultural and political order: sexuality, particularly sexual relations between 'whites' and 'blacks' and 'mixed race' people that produce legitimate 'mulatto' offspring in mixed race marriages. ${ }^{26}$ Uerlings states from historic documents the view at the time: 'die fehlende Kontrolle der eigenen Triebe führt in ein allgemeines Chaos. Solche Kontrolle kann man von Schwarzen kaum erwarten, die moralischen Vorwürfe gehen an die Adresse der Weißen'. ${ }^{27}$ Uerlings terms this notion 'negative Sexualisierung' and refers to Sander L. Gilman to provide a wider context:

Eben jene unkontrollierte Sexualität deuten Historiker wie J.J. Bachofen als Zeichen des 'Sumpfes', der frühesten Phase der Menscheitsgeschichte. Schwarze, wenn man Hegel wie Schopenhauer Glauben schenken will, sind auf dieser primitivsten Stufe stehen geblieben, und ihr Dasein in der heutigen Welt dient als Indikator dafür, wie weit es der Menschheit gelungen ist, Kontrolle über sich und die Welt zu gewinnen. Der Verlust von Kontrollmöglichkeiten zeigt sich im Rückgriff auf die dunkle Vergangenheit, die 
Degeneration in dem primitiven Ausdruck von Emotionen in Form von Wahnsinn oder ungezügelter Sexualität. ${ }^{28}$

The parallels with Heyse's portrayal of Wally's 'dark and primitive' paternal side are obvious. The power and allure of her 'black sexuality', not sufficiently hidden behind her demure dress, is hinted at throughout, and her eventual madness fits the uncontrolled 'primitive' expression of emotion.

However, the central problem that links the French colonial context with Heyse's novella lies not within the 'mulatto' generation but with their parents and grandparents. The 'moralischen Vorwürfe [...] an die Adresse der Weißen' referred to by Uerlings are echoed in Stephan's reading of 'Heyses Novelle als Warnung vor "Mésaillancen" [...] und als eine Aufforderung, das "deutsche Blut" reinzuhalten' addressed at 'die Großeltern- und Elterngeneration' ${ }^{29}$ In particular, Wally's 'white' grandmother is to be held responsible for her granddaughter's unhappy life. Wally's grandfather is portrayed as the stereotypical uncontrolled 'black' 'Sohn der Wildnis' (323) who shows signs of 'degeneration' (as outlined above by Gilman) through his laziness, his brutality towards his wife, his craving for pleasure and alcoholism that all contribute to his early death. When Wally mockingly comments that she had not been careful enough in 'her choice' of grandfather (334), it is clear that her grandmother had failed to make the 'right choice' of husband and father. It seems that the Parisian 'Madame Wally' (324) had become too 'French' (through too many 'Putzwaren'?) and too inflamed by the desire the 'black' man sparked off in her. Although we encounter here a role reversal of the usual colonial pairing of a 'white' man with 'black' woman, the relationship of the 'nicht mehr ganz junge Dame' (323) with her 'gravitätischen Othello' fits Uerlings' model of 'negative Sexualisierung' that in itself is part of a long tradition of sexualised 'black bodies'. In her eager pursuit of the 'schon sehr zivilisierten Sohn der Wildnis' the 'sterblich verliebt[e]' Madame Wally takes on the sexualised role of a hunter (323). By giving grandmother and granddaughter the same name, Heyse allows the reader not only to see the 'good' grandmotherly German side in the 'Munich Wally' but also warns against 'dark' traits and sexual desires in the 'gute deutsche Frau' (323). 
However, Heyse's emphasis on the female is clearly more than the integration of some risqué sexual hints 'die sich letztlich doch innerhalb der Grenzen des bürgerlichen Liberalismus bewegte[n] und vor letzten Konsequenzen [zurückschreckten]'. ${ }^{30}$ The focus on the (grand)mother fits in with one of the central elements in most adaptations of the Medea myth: the 'mad and bad' mother. The fact that Heyse's text emphasises not the sins of the fathers but the sins of the (grand)mothers can be read in connection with the growing importance of motherhood with regard to eugenic family planning.

Wally herself appears in this context as no more than the unfortunate product of a mésalliance and evokes pity rather than fear. She is miles away from the strong, threatening classical Medea, and her breakdown is presented as almost biologically predetermined through the conflict of her differing 'Blut'. Wally does not show the intriguing complexity of the classical Medea who is a woman torn but in her right mind, commits horrific murders and escapes scot-free to leave a society that has been shaken in its very core values. Wally is being denied any such agency and ultimately fits the stereotype of the 'mad and bad' 'mulatto woman' who kills her own child. Unlike that of the classical Medea, her act does not have radical implications because the element of challenge to boundaries as well as to political, cultural and racial oppression is nullified. Locked up in a mental asylum, put into a strait-jacket and finally 'erlöst' (355) through an early death, she is confined to a place of passivity and silence.

1 Michael Georg Conrad, Von Emile Zola bis Gerhart Hauptmann, Leipzig 1902, p. 22. See also Oliver Pholmann, 'Literaturkritik in der literarischen Moderne', in Literaturkritik: Geschichte, Theorie, Praxis, ed. Thomas Anz and Rainer Baasner, Munich 2004, pp. 94-112.

2 The literature about Medea reception in German-speaking literature is extensive. Some recent examples include: Yixu Lü, Medea unter den Deutschen. Wandlungen einer literarischen Figur, Freiburg im Breisgau/ Berlin/ Vienna 2009; Inge Stephan, Medea: Multimediale Karriere einer mythologischen Figur, Cologne 2006; Britta Schmierer, Motivation in Medeatragödien der Antike und der Gegenwart, Würzburg 2005; Christoph Steskal, Medea und Jason in der deutschen Literatur des 20. Jahrhunderts, Regensburg 2001.

3 Bernard Knox, Word and Action: Essay on Ancient Theater, Baltimore 1979, p. 330. 4 Quoted in Sigrid von Moisy, Paul Heyse. Münchner Dichterfürst im Bürgerlichen Zeitalter. Ausstellung in der Bayerischen Staatsbibliothek, 23. Januar bis 11. April 1981 (Ausstellungskataloge der Bayerischen Staatsbibliothek 23), Munich 1981, p. 90. Moisy points out that Heyse also published an essay on Grillparzer in Literatur-Blatt des Deutschen Kunstblattes (Oct. 1858) (ibid.). 
5 Franz Grillparzer (1791-1872) composed his adaptation of the Medea myth, entitled Das goldene Vließ (first performed 1821 in Vienna's Burgtheater), as a trilogy. Whilst the third part, 'Medea', deals with Medea's fate in Corinth, the first two parts, 'Der Gastfreund' and 'Die Argonauten', provide further background. Grillparzer stressed that the three parts should be staged together.

6 Paul Heyse, Gesammelte Werke (Gesamtausgabe), ed. Markus Bernauer and Norbert Miller, 5 Reihen, Hildesheim 1995 [reprint], IV/2, Novellen und Erzählungen 1888-1900, pp. 319-55 (p. 342). Further references appear in the text.

7 Medea: Essays on Medea in Myth, Literature, Philosophy and Art, eds. James J. Clauss and Sarah Iles Johnston, Princeton 1997, p. 8.

8 See the title of Marianne McDonald's essay: 'Medea as Politician and Diva: Riding the Dragon into the Future', in Medea: Essays on Medea, pp. 297-324.

9 Urzula Bonter, Das Romanwerk von Paul Heyse, Würzburg 2007, p. 125.

10 Usually Wally is the abbreviated version of the old German name Walburga but it can also be used for Waltraud. Walburga is the name of a female saint who was canonised on the first of May and known for her use of healing herbs and plants to protect against the plague, rabies and other diseases. It is an interesting question to ask whether Heyse intended a subtle link to the classical Medea's contrasting background of healing powers and witchcraft by evoking Die Heilige Walburga and Walpurgisnacht. Connected through the date, the latter names the pagan meeting of witches who ride their broomsticks around the Blocksberg during the last night of April.

11 Stephan, Medea, p. 59

12 Heyse's text was written at a time when 'race' was approached in very different ways and with a very different terminology from now. In order to discuss this the following essay needs to deploy a number of unsatisfactory and contested terms, like 'mulatto', 'black', 'white', which are set in quotation marks to signal their problematic use.

13 Stephan, Medea, p. 56

14 Ibid., pp. 56-9.

15 Steskal, Medea und Jason, pp. 112 and 140.

16 Marianna Thalden, Medea. A Study in the Adaptability of a Literary Theme, Diss., Pennsylvania State University 1972, p. 144. Quoted in Kai Stalmann, Geschlecht und Macht. Maskuline Identität und künstlerischer Anspruch im Werk Hans Henny Jahnns, Cologne 1998, p. 184.

17 Herbert Uerlings, Poetiken der Interkulturalität. Haiti bei Kleist, Seghers, Müller, Tübingen 1997, p. 22.

18 Anette Dietrich, Weiße Weiblichkeiten. Konstruktionen von 'Rasse' und Geschlecht im deutschen Kolonialismus, Bielefeld 2007, p. 138.

19 Compare George L. Mosse, Die Geschichte des Rassismus in Europa, Frankfurt a.M. 1990, esp. pp. 47-9.

20 Kai Stalmann, Geschlecht und Macht, p. 186. See also Stephan, Medea, p. 63.

21 Ann Laura Stoler, Race and the Education of Desire. Foucault's History of Sexuality and the Colonial Order of Things, Durham, NC 1995, p. 27.

22 Fatima El-Tayeb, Schwarze Deutsche, Frankfurt a.M./New York 2001; Dietrich, Weiße Weiblichkeiten, 2007.

23 Paul Heyse, Medea. Er soll dein Herr sein. Zwei Novellen. Illustriert von René Reinicke, Stuttgart no year [1898], pp. 21 and 49.

24 Rita Gudermann and Bernhard Wulff show how images of the 'Mohr' in Germany are closely linked to Germany's colonial activities and increased fascination with Africa and its people in the late nineteenth and early twentieth century. Rita Gudermann and Bernhard Wulff, Der SarottiMohr. Die bewegte Geschichte einer Werbefigur, Berlin 2004.

25 Uerlings, Poetiken, p. 21.

26 This assessment supports Stoler's claim that any history of European nineteenth-century racism has to be a history of its sexuality and vice versa (Stoler, Race, 1995).

27 Uerlings, Poetiken, p. 21. 
28 Sander L. Gilman, 'Hottentottin und Prostituierte. Zu einer Ikonographie der sexualisierten Frau', in Gilman, Rasse, Sexualität und Seuche. Stereotype aus der Innenwelt der westlichen Kultur, Reinbek bei Hamburg 1992, pp. 119-54 (p. 139) (quoted in Uerlings, Poetiken, p. 21). 29 Stephan, Medea, pp. 58-9.

30 Moisy, Paul Heyse, p. 220. 